\title{
Poly[tetraaquatriglutaratodicerium(III) decahydrate], a novel luminescent metal-organic framework possessing hydrophilic hexagonal channels
}

\author{
REMYA M NAIR ${ }^{\mathrm{a}}$, M R SUDARSANAKUMAR ${ }^{\mathrm{a}, \mathrm{b}, *}, \mathrm{~S} \mathrm{SUMA}^{\mathrm{c}}$, \\ M R PRATHAPACHANDRA KURUP ${ }^{d}$ and P K SUDHADEVI ANTHARJANAM ${ }^{\mathrm{e}}$ \\ aPresent address: Department of Chemistry, Mahatma Gandhi College, Thiruvananthapuram, \\ Kerala, 695004 India \\ ${ }^{b}$ VTM NSS College, Dhanuvachapuram, Thiruvananthapuram, Kerala, 695503 India \\ ${ }^{c}$ Department of Chemistry, S N College, Chempazhanthy, Thiruvananthapuram, Kerala, 695587 India \\ ${ }^{\mathrm{d} D e p a r t m e n t}$ of Applied Chemistry, Cochin University of Science and Technology, Kochi, \\ Kerala, 682 022, India

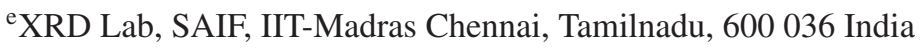 \\ e-mail: sudarsanmr@gmail.com
}

MS received 22 December 2015; revised 21 May 2016; accepted 2 July 2016

\begin{abstract}
A novel 2D metal-organic framework poly[tetraaquatriglutaratodicerium(III) decahydrate] with an open framework structure has been successfully grown by single gel diffusion technique. Sodium metasilicate was used for gel preparation. The structure was determined by single crystal X-ray diffraction. The compound crystallizes in orthorhombic space group Pnma and possesses a structure consisting of $\left[\mathrm{CeO}_{10}\right]$ polyhedra and $\mathrm{H}_{2} \mathrm{O}$ molecules with hydrophilic hexagonal channels. The crystals were further characterized by elemental analysis, FT-IR and UV-Visible spectroscopy, powder X-ray diffraction and thermogravimetry. The luminescent property and magnetic susceptibility of the complex were also investigated.
\end{abstract}

Keywords. Metal-organic framework; gel method; 2D complex; porous architecture; hydrophilic channels; luminescence.

\section{Introduction}

Studies on metal-organic framework materials have become a fascinating topic over the past decades owing to their interesting properties and intriguing structural motifs. Metal-organic frameworks (MOFs) have potential applications in many fields such as gas storage, adsorption, shape selective seperation, catalysis, ionexchange, non-linear optics and so on. ${ }^{1-6}$ Rare earth elements have considerable application in technological fields. ${ }^{7-9}$ Owing to the unique nature of lanthanide ions such as their large radius, high and variable coordination numbers, they have been employed for the construction of MOFs having excellent magnetic and luminescent properties. ${ }^{10-13}$ However, it is still a great challenge to synthesise lanthanide complexes of desired topology due to a number of challenging factors. Hence, judicious and rational choice of organic ligands is a crucial element in the synthesis and design of lanthanide MOFs. For the construction of these MOFs, flexible dicarboxylates with $-\mathrm{CH}_{2}$ - spacer are usually selected.

\footnotetext{
*For correspondence
}

Unlike rigid aromatic dicarboxylates, they can bend and rotate freely when coordinated to metal centres, causing structural pecularities and producing unique structures. Glutaric acid, the next higher homologue of succinic acid is an excellent flexible ligand and can exhibit abundant coordination modes thus giving rise to extended structures with dimensionalities ranging from 1D to 3D. ${ }^{14-16}$ It was well-established that lanthanides have a strong tendency to coordinate to O-donor atoms to form lanthanide-carboxylate coordination polymers. ${ }^{17}$ Moreover, crystallization of metal glutarates by gel method is limited in the literature. ${ }^{18}$

Taking into account all these factors, we have grown a novel 2D porous lanthanide MOF, poly[tetraaquatriglutaratodicerium(III) decahydrate $]\left(\left[\mathrm{Ce}_{2}(\mathrm{glu})_{3}\left(\mathrm{H}_{2} \mathrm{O}\right)_{4}\right] \cdot 10 \mathrm{H}_{2} \mathrm{O}\right)_{\mathrm{n}}$ possessing hydrophilic hexagonal channels. To the best of our knowledge, this is the first report of the title compound. Crystal structure of a related compound viz., poly([tetraaqua- $\mu_{4}$-glutarato-cerium(III) $]$ chloride dihydrate) was reported ${ }^{19}$ which is an ionic $2 \mathrm{D}$ open framework compound with $\mathrm{Cl}^{-}$as the counter ion but our compound possesses a different structure compared to the reported one. The crystals grown were 
further characterized by elemental analysis, FT-IR and UV-Visible spectroscopy, thermogravimetry, powder $\mathrm{X}$-ray and single crystal X-ray diffraction studies. The luminescent property and magnetic susceptibility of the complex were also investigated.

\section{Experimental}

\subsection{Materials and methods}

Glutaric acid $(\mathrm{CDH})$ and cerium nitrate $(\mathrm{CDH})$ were of AR grade and used without further purification. The carbon and hydrogen content present in the grown crystals were found using Elementer Vario-EL 111 CHNS analyzer. The FT-IR spectrum was recorded using $\mathrm{KBr}$ pellets on a Thermo Nicolet, Avatar 370 spectrometer in the range $4000-400 \mathrm{~cm}^{-1}$. Powder X-ray diffraction studies were carried out using a Bruker AXS D8 advance XRD with $\mathrm{Cu} \mathrm{K} \alpha$ radiation $(\lambda=1.54056 \AA$ ). The solid state optical absorption spectrum was recorded using Varian Cary 5000 UV-VisibleNIR spectrometer in the range $200-1200 \mathrm{~nm}$. The thermal analysis of the crystals was carried out using a Perkin Elmer Diamond TG/DTG analyzer instrument at a heating rate of $10^{\circ} \mathrm{C} / \mathrm{min}$ in nitrogen atmosphere. The photoluminescence spectra of the ligand and the complex were recorded using JY Horiba PL meter at room temperature. Magnetic susceptibility measurement of the sample was carried out using Sherwood Scientific MK-1 magnetic susceptibility meter.

\subsection{Growth procedure of $\left(\left[\mathrm{Ce}_{2}(\mathrm{glu})_{3}\left(\mathrm{H}_{2} \mathrm{O}\right)_{4}\right] \cdot 10 \mathrm{H}_{2} \mathrm{O}\right)_{n}$}

Single gel diffusion technique was used for growing quality crystals of $\left(\left[\mathrm{Ce}_{2}(\mathrm{glu})_{3}\left(\mathrm{H}_{2} \mathrm{O}\right)_{4}\right] \cdot 10 \mathrm{H}_{2} \mathrm{O}\right)_{\mathrm{n}} \cdot{ }^{20-22}$ Silica hydrogel prepared from an aqueous solution of sodium metasilicate (SMS) was employed for this purpose. A series of experiments were conducted for obtaining good quality crystals and the optimum conditions for crystal growth are as follows: [glutaric acid] $=1 \mathrm{M}$, [cerium nitrate $=0.5 \mathrm{M}$, gel density $=1.04 \mathrm{~g} \mathrm{~cm}^{-3}$ and $\mathrm{pH}=5.5$. Anal. Calcd for $\left(\left[\mathrm{Ce}_{2}(\mathrm{glu})_{3}\left(\mathrm{H}_{2} \mathrm{O}\right)_{4}\right] \cdot 10 \mathrm{H}_{2} \mathrm{O}\right)_{\mathrm{n}}: \mathrm{C}, 19.50 \% ; \mathrm{H}, 4.98 \%$. Found: C, 19.68\%; H, 4.57\%. FT-IR $\left(\mathrm{KBr} \mathrm{cm}{ }^{-1}\right)$ 3413b, 1540vs, 1417vs, 2970w, 1058m, 645s. Magnetic moment ( $\mu$, B.M.): 2.56 .

\subsection{Single crystal $X$-ray diffraction analysis}

The single crystal X-ray diffraction studies were carried out using a Bruker AXS Kappa Apex2 CCD diffractometer at room temperature with graphite monochromated Mo $\mathrm{K} \alpha(\lambda=0.71073 \AA)$ radiation. The unit

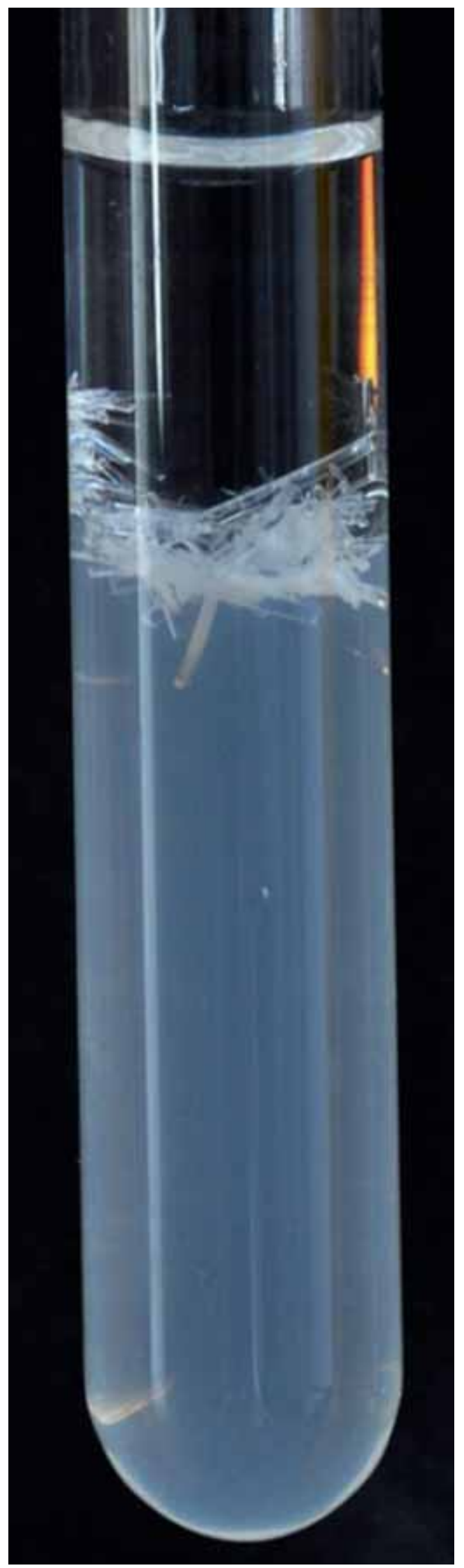

Figure 1. Photograph of crystalline $\left(\left[\mathrm{Ce}_{2}(\mathrm{glu})_{3}\left(\mathrm{H}_{2} \mathrm{O}\right)_{4}\right]\right.$. $\left.10 \mathrm{H}_{2} \mathrm{O}\right)_{\mathrm{n}}$. 
cell dimensions and intensity data were recorded at $293 \mathrm{~K}$. The program SAINT/XPREP was used for data reduction and APEX2/SAINT for cell refinement. ${ }^{23}$ The structure was solved by SIR92 and refined by fullmatrix least squares on $\mathrm{F}^{2}$ using SHELXL-97 computer programs. ${ }^{24}$ All non-hydrogen atoms were refined with anisotropic thermal parameters. Carbon-bound $\mathrm{H}$ atoms were placed in calculated positions and included in the refinement in the riding model approximation. The hydrogen atoms of the lattice water molecules could not be located in the difference Fourier map, and were not included in the structure. DIAMOND software version $3.1 \mathrm{f}$ was employed for structure plotting. ${ }^{25}$

\section{Results and Discussion}

\subsection{Crystal growth}

Transparent, good quality single crystals essential for single crystal X-ray diffraction studies appeared at the gel interface after 5 days. Fully grown crystals were carefully separated from the gel interface, washed several times with distilled water to remove gel impurities and finally dried. Figure 1 shows the photograph of crystalline $\left(\left[\mathrm{Ce}_{2}(\mathrm{glu})_{3}\left(\mathrm{H}_{2} \mathrm{O}\right)_{4}\right] \cdot 10 \mathrm{H}_{2} \mathrm{O}\right)_{\mathrm{n}}$.

\subsection{Powder X-ray diffraction studies}

Powder X-ray diffraction studies were carried out using a Bruker AXS D8 advance XRD with $\mathrm{Cu} \mathrm{K} \alpha$ radiation $(\lambda=1.54056 \AA)$. The crystalline nature of the complex was confirmed from the well defined Braggs peaks at specific $2 \theta$ angles. The phase purity of the bulk sample was determined by comparing the powder XRD pattern with the simulated one obtained from single crystal X-ray diffraction data using the Mercury software. ${ }^{26}$ Experimental and simulated powder X-ray diffractograms are shown in Figure 2. As shown, the peak positions of the experimental pattern of the complex match well with the simulated one, confirming that the complex had been obtained as pure crystalline phase. Slight differences observed may be due to the preferred orientation of the powder sample.

\subsection{Crystal structure of $\left(\left[\mathrm{Ce}_{2}(\mathrm{glu})_{3}\left(\mathrm{H}_{2} \mathrm{O}\right)_{4}\right] \cdot 1 \mathrm{OH}_{2} \mathrm{O}\right)_{n}$}

X-ray single crystal analysis reveals that the title compound is a $2 \mathrm{D}$ metal-organic framework possessing hydrophilic hexagonal channels with interconnected $\left[\mathrm{CeO}_{10}\right]$ polyhedra. The compound crystallizes in orthorhombic Pnma space group. The corresponding unit cell parameters are $\mathrm{a}=8.75270(10) \AA$, $\mathrm{b}=30.9753(5) \AA, \mathrm{c}=13.0054(2) \AA, \alpha=\beta=\gamma=90^{\circ}$.

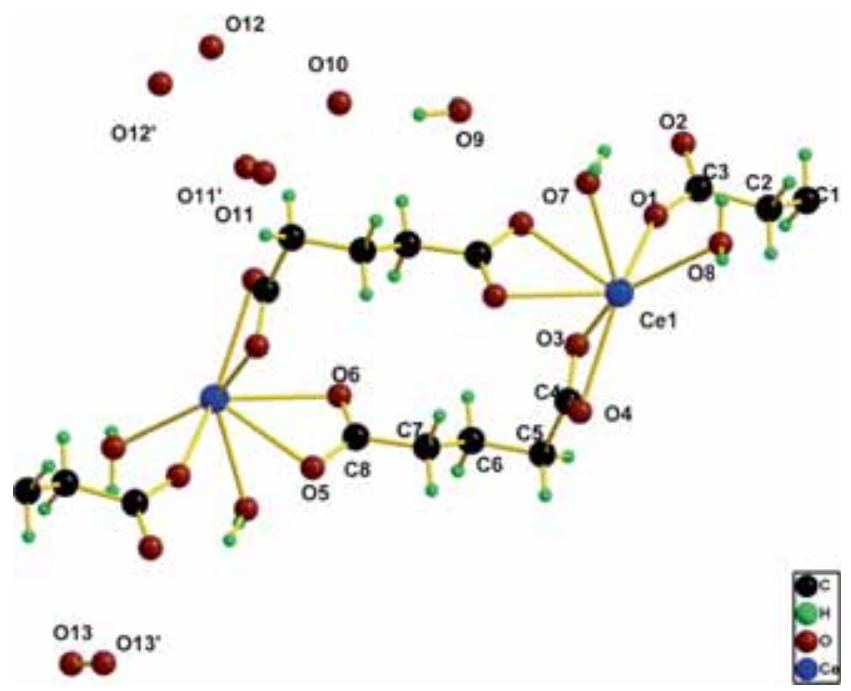

Figure 3. Asymmetric unit of $\left(\left[\mathrm{Ce}_{2}(\mathrm{glu})_{3}\left(\mathrm{H}_{2} \mathrm{O}\right)_{4}\right] \cdot 10 \mathrm{H}_{2} \mathrm{O}\right)_{\mathrm{n}}$.

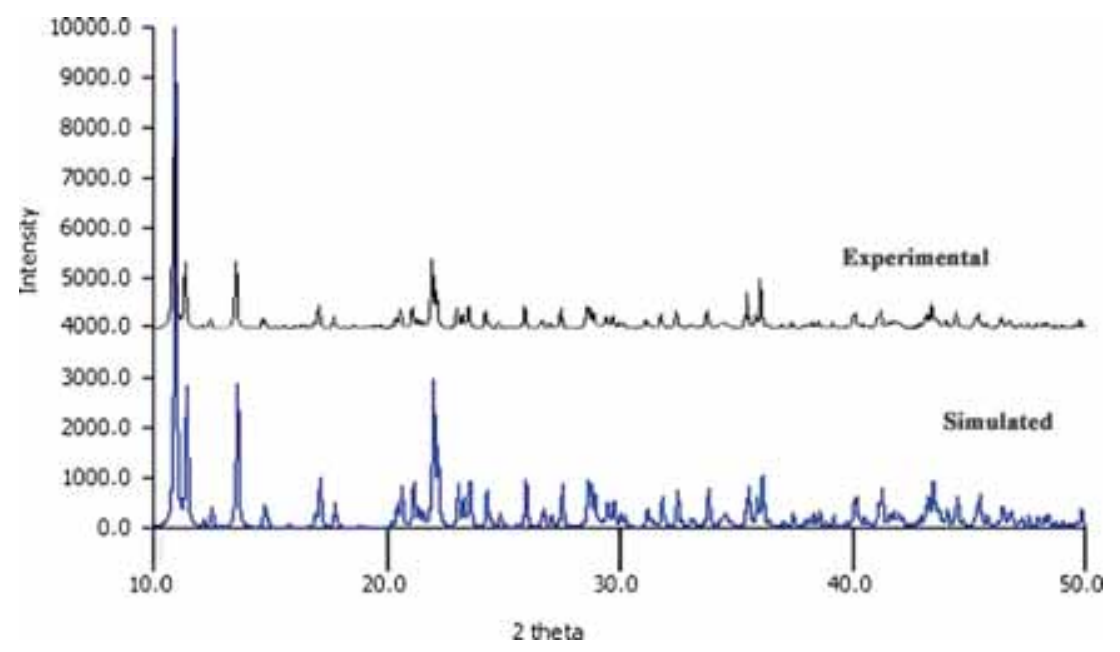

Figure 2. Experimental and simulated X-ray diffractogram of $\left(\left[\mathrm{Ce}_{2}(\text { glu })_{3}\left(\mathrm{H}_{2} \mathrm{O}\right)_{4}\right] \cdot 10 \mathrm{H}_{2} \mathrm{O}\right)_{n}$. 
Table 1. Crystal data and structure refinement parameters of $\left(\left[\mathrm{Ce}_{2}(\mathrm{glu})_{3}\left(\mathrm{H}_{2} \mathrm{O}\right)_{4}\right]\right.$. $\left.10 \mathrm{H}_{2} \mathrm{O}\right)_{\mathrm{n}}$.

\begin{tabular}{|c|c|}
\hline Parameters & $\left(\left[\mathrm{Ce}_{2}(\mathrm{glu})_{3}\left(\mathrm{H}_{2} \mathrm{O}\right)_{4}\right] \cdot 10 \mathrm{H}_{2} \mathrm{O}\right)_{\mathrm{n}}$ \\
\hline Empirical formula & $\mathrm{C}_{15} \mathrm{H}_{46} \mathrm{Ce}_{2} \mathrm{O}_{26}$ \\
\hline Formula weight (M) & 922.76 \\
\hline Temperature $(\mathrm{T})(\mathrm{K})$ & $296(2)$ \\
\hline Wavelength $(\operatorname{Mo~K\alpha })(\AA)$ & 0.71073 \\
\hline Crystal system & Orthorhombic \\
\hline Space group & Pnma \\
\hline Unit cell dimensions & $\begin{array}{l}\mathrm{a}(\AA)=8.75270(10), \alpha=90^{\circ} \\
\mathrm{b}(\AA)=30.9753(5), \beta=90^{\circ} \\
\mathrm{c}(\AA)=13.0054(2), \gamma=90^{\circ}\end{array}$ \\
\hline Volume V $\left(\AA^{3}\right)$ & $3525.99(9)$ \\
\hline Z, Dcalc $(\rho)(\mathrm{Mg} / \mathrm{m} 3)$ & $4,1.708$ \\
\hline Absorption Coefficietnt, $\mu$ (mm-1) & 2.636 \\
\hline $\mathrm{F}(000)$ & 1840 \\
\hline Crystal size $\left(\mathrm{mm}^{3}\right)$ & $0.30 \times 0.25 \times 0.20$ \\
\hline Colour, nature & colourless, block \\
\hline$\theta$ Range for data collection $\left(^{\circ}\right)$ & 2.52 to 25.00 \\
\hline Independent reflections $\left(\mathrm{R}_{\text {int }}\right)$ & 0.0744 \\
\hline Limiting indices & $-10 \leq \mathrm{h} \leq 10,-23 \leq \mathrm{k} \leq 36,-13 \leq \mathrm{l} \leq 15$ \\
\hline Reflections collected/ unique & $1890 \overline{3}$ \\
\hline Completeness to $\theta$ & $99.9 \%$ \\
\hline Absorption correction & Semi-empirical from equivalents \\
\hline Max. and min. transmission & 0.679 and 0.581 \\
\hline Refinement method & Full-matrix least squares on $\mathrm{F}^{2}$ \\
\hline Data /restraints/parameters & $3171 / 71 / 246$ \\
\hline Goodness-of-fit on $\mathrm{F}^{2}$ & 1.258 \\
\hline Final $\mathrm{R}$ indices $[(\mathrm{I}>2 \sigma(\mathrm{I})]$ & $\mathrm{R}_{1}=0.0446, \mathrm{wR}_{2}=0.1024$ \\
\hline $\mathrm{R}$ indices (all data) & $\mathrm{R}_{1}=0.0504, \mathrm{wR}_{2}=0.1069$ \\
\hline Largest difference peak and hole $\left(\mathrm{e} \AA^{-3}\right)$ & 1.235 and -1.870 \\
\hline
\end{tabular}

$\mathrm{R}_{1}=\Sigma\left\|\mathrm{F}_{\mathrm{o}}|-| \mathrm{F}_{\mathrm{c}}\right\| / \Sigma \mid \mathrm{F}_{\mathrm{o}}: \mathrm{wR}_{2}=\left[\Sigma \mathrm{w}\left(\mathrm{F}_{\mathrm{o}}^{2}-\mathrm{F}_{\mathrm{c}}^{2}\right)^{2} / \Sigma \mathrm{w}\left(\mathrm{F}_{\mathrm{o}}^{2}\right)^{2}\right]^{1 / 2}$

The asymmetric unit of $\left(\left[\mathrm{Ce}_{2}(\mathrm{glu})_{3}\left(\mathrm{H}_{2} \mathrm{O}\right)_{4}\right] \cdot 10 \mathrm{H}_{2} \mathrm{O}\right)_{\mathrm{n}}$ along with atom numbering scheme is shown in Figure 3. The crystallographic data along with details of structure solution refinements are given in Table 1 and some selected bond lengths and bond angles are presented in Table S1 (Supplementary Information). There is one crystallographically unique cerium atom, one and a half glutarate, two coordinated and five lattice water molecules in the asymmetric unit. Of the five lattice water molecules, three are disordered into several positions (O11, O12 and O13). The asymmetric unit excluding the lattice water molecules are shown in Figure S1 (Supplementary Information). The presence of these coordinated and lattice water molecules provides crystalline stability for the complex via a network of hydrogen bonding interactions.

The coordination environment of $\left(\left[\mathrm{Ce}_{2}(\mathrm{glu})_{3}\left(\mathrm{H}_{2} \mathrm{O}\right)_{4}\right]\right.$. $\left.10 \mathrm{H}_{2} \mathrm{O}\right)_{\mathrm{n}}$ is shown in Figure 4. As shown, each cerium atom is decacoordinated with respect to eight oxygen atoms from five different glutarate moieties and the remaining two are from coordinated water molecules to form a slightly distorted $\left[\mathrm{CeO}_{10}\right]$ polyhedron while in the related reported structure, ${ }^{19}$ cerium(III) ion shows a coordination number of nine defined by four water

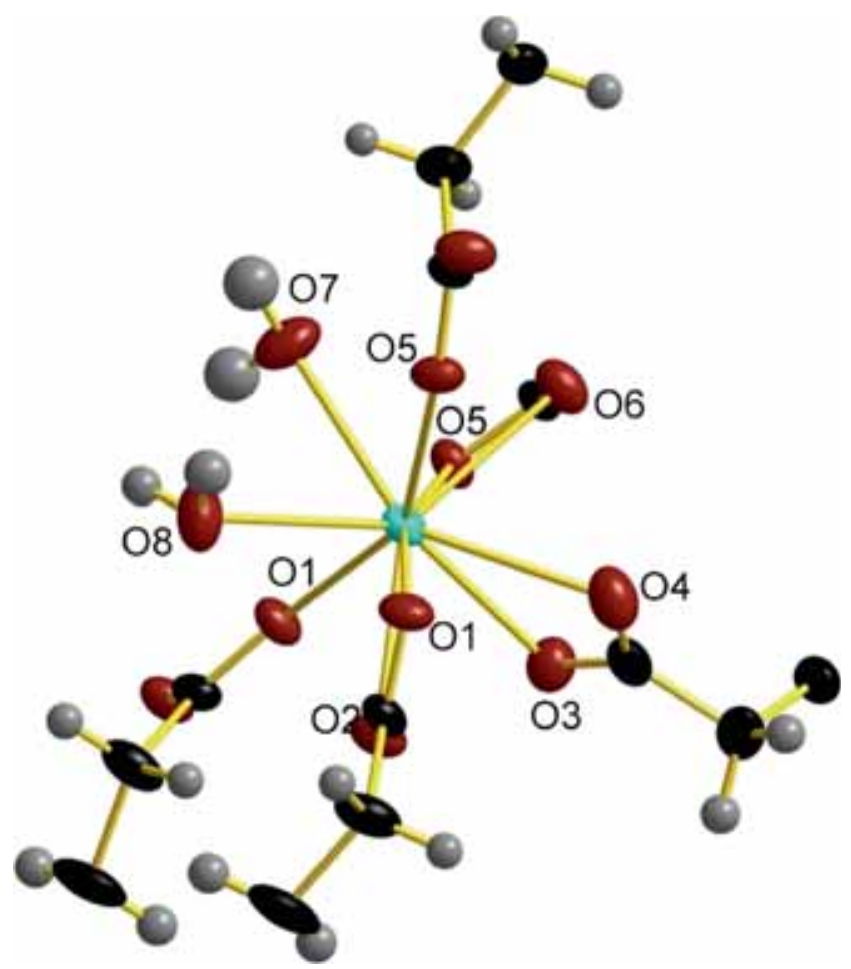

Figure 4. Coordination environment of $\left(\left[\mathrm{Ce}_{2}(\mathrm{glu})_{3}\left(\mathrm{H}_{2} \mathrm{O}\right)_{4}\right]\right.$. $\left.10 \mathrm{H}_{2} \mathrm{O}\right)_{\mathrm{n}}$. 
oxygen atoms and five carboxylate oxygen atoms from glutarato ligands. In this complex, three of the carboxylate groups are coordinated to the metal ion in a typical bidentate mode and the remaining ones coordinate in a monodentate manner. Through the bidentate coordination, the compound gets chelated which further enhances the stability of the complex. The $\mathrm{Ce}-\mathrm{O}$ bond lengths are in the range of 2.444(4) $\AA$ to 2.756(4) $\AA$ and the bond lengths of $\mathrm{Ce}-\mathrm{O} 7$ and $\mathrm{Ce}-\mathrm{O} 8$ are 2.611(5) and 2.555(5) $\AA$, respectively. The $\mathrm{Ce}-\mathrm{O}$ bond distances are comparable to those observed in other $\mathrm{Ce}(\mathrm{III}) \mathrm{com}$ plexes except $\mathrm{Ce}-\mathrm{O} 1 \# 6=2.729(4)$, symmetry code: $\# 6$ $\mathrm{x}+1 / 2, \mathrm{y},-\mathrm{z}+1 / 2$ and $\mathrm{Ce}-\mathrm{O} 5 \# 3=2.756(4)$, symmetry code: $\# 3-x+1,-y+1,-z+1$, which is a little longer than the literature value. However, the average value of these bond distances is consistent with the reported values for other Ce(III) complexes. ${ }^{19,27}$ The carboxylate groups of the glutarate moiety exhibit two types of coordination mode in $\left(\left[\mathrm{Ce}_{2}(\mathrm{glu})_{3}\left(\mathrm{H}_{2} \mathrm{O}\right)_{4}\right] \cdot 10 \mathrm{H}_{2} \mathrm{O}\right)_{\mathrm{n}}$. In the first case, the carboxylate groups are found to coordinate tridentately on both ends of the molecule and adopt a $\mu_{2}-\eta^{2}$, $\eta^{1}$ bridging mode and in the latter case, the carboxylate groups are found to coordinate tridentately on one side and bidentately on the other side. Thus, the carboxylate oxygens of the glutarate moiety can act both as bis-bridging and bis-chelating unit.

In this structure, the adjacent $\left[\mathrm{CeO}_{10}\right]$ polyhedra are connected via bridging oxygen atoms (O1 and O5) of the carboxylate groups of glutarate and the bridging of the cerium centres by the glutarate oxygens results in the formation of $\mathrm{O}-\mathrm{Ce}-\mathrm{O} 1 \mathrm{D}$ polymeric chains (Figure 5). Within this 1D chain, Ce... Ce non-bonding distance is found to be 4.3854(4) $\AA$. These 1D chains are then interconnected by the pillaring glutarate units to form the 2D structure. The perspective view of the 2D structure along the crystallographic ' $c$ ' axis is shown in Figure 6. An importantant characteristic of this structure is the presence of hexagonal channels. Lattice water molecules are found to be entrapped in some of these channels which make them hydrophilic. The polyhedral design of the compound clearly presents these hexagonal channels (Figure 7). It was well-established that porous MOFs have potential applications in the field of gas storage and adsorption. ${ }^{28,29}$

The hydrogen bonding interactions are summarized in Table 2. Here, the lattice water molecule 09 acts

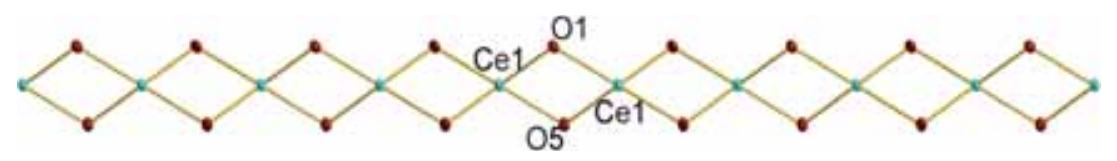

Figure 5. 1D polymeric chain formed by bridging oxygen atoms.

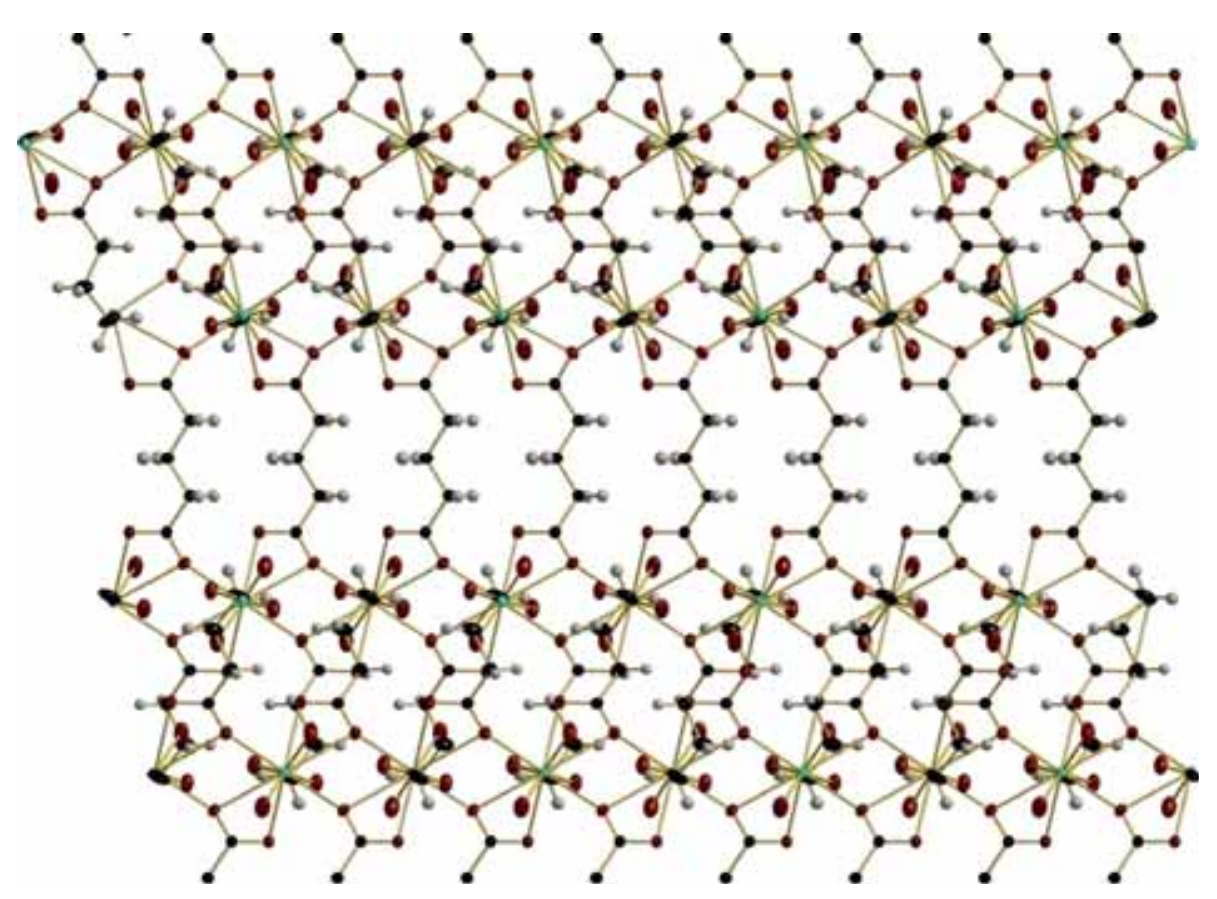

Figure 6. Perspective view of the $2 \mathrm{D}$ structure of $\left(\left[\mathrm{Ce}_{2}(\mathrm{glu})_{3}\left(\mathrm{H}_{2} \mathrm{O}\right)_{4}\right] \cdot 10 \mathrm{H}_{2} \mathrm{O}\right)_{\mathrm{n}}$ along 'c' axis. (Lattice water molecules are omitted for clarity). 


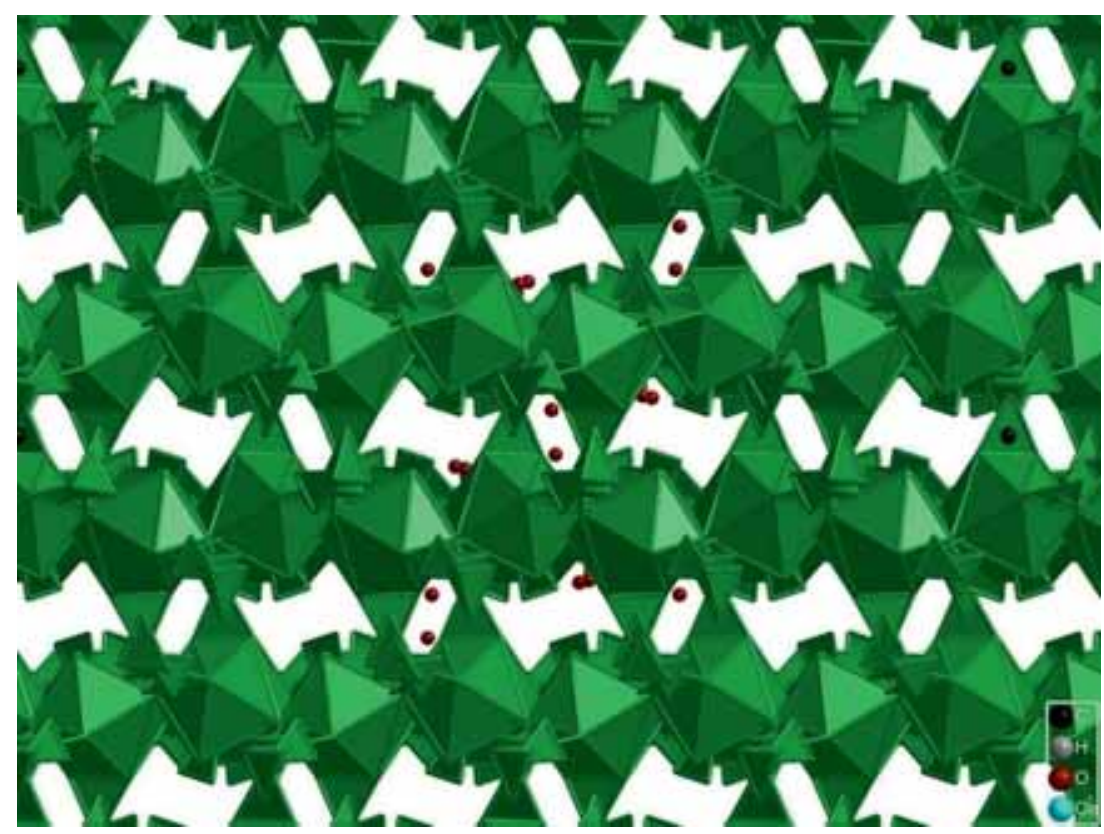

Figure 7. Polyhedral view of hydrophilic hexagonal channels in $\left(\left[\mathrm{Ce}_{2}(\mathrm{glu})_{3}\left(\mathrm{H}_{2} \mathrm{O}\right)_{4}\right] \cdot 10 \mathrm{H}_{2} \mathrm{O}\right)_{\mathrm{n}}$.

Table 2. Hydrogen bonds for $\left(\left[\mathrm{Ce}_{2}(\mathrm{glu})_{3}\left(\mathrm{H}_{2} \mathrm{O}\right)_{4}\right] \cdot 10 \mathrm{H}_{2} \mathrm{O}\right)_{\mathrm{n}}$.

\begin{tabular}{|c|c|c|c|c|}
\hline D-H $\cdots \mathbf{A}$ & $\mathbf{d}(\mathbf{D}-\mathbf{H})(\AA)$ & $\mathbf{d}(\mathbf{H} \cdots \mathbf{A})(\AA)$ & $\mathbf{d}(\mathbf{D} \cdots \mathbf{A})(\AA)$ & $<($ DHA $)\left(^{\circ}\right)$ \\
\hline $\mathrm{C}(2)-\mathrm{H}(2 \mathrm{~B}) \cdots \mathrm{O}(2) \# 6$ & 0.97 & 2.51 & $3.369(8)$ & 148.2 \\
\hline $\mathrm{O}(8)-\mathrm{H}(8 \mathrm{~A}) \cdots \mathrm{O}(10) \# 7$ & $0.89(2)$ & $1.93(3)$ & $2.798(12)$ & $165(6)$ \\
\hline $\mathrm{O}(8)-\mathrm{H}(8 \mathrm{~B}) \cdots \mathrm{O}(3) \# 6$ & $0.89(2)$ & $1.84(2)$ & $2.723(7)$ & 170(7) \\
\hline $\mathrm{O}(7)-\mathrm{H}(7 \mathrm{C}) \cdots \mathrm{O}(9) \# 7$ & $0.904(15)$ & $1.94(5)$ & $2.769(7)$ & $153(8)$ \\
\hline $\mathrm{O}(9)-\mathrm{H}(9 \mathrm{~A}) \cdots \mathrm{O}(10)$ & $0.90(2)$ & $2.14(3)$ & $2.999(15)$ & $158(6)$ \\
\hline $\mathrm{O}(9)-\mathrm{H}(9 \mathrm{~B}) \cdots \mathrm{O}(6) \# 8$ & $0.90(2)$ & $1.87(2)$ & $2.760(7)$ & 171(9) \\
\hline $\mathrm{O}(7)-\mathrm{H}(7 \mathrm{D}) \cdots \mathrm{O}(4) \# 2$ & $0.91(2)$ & $1.89(4)$ & $2.766(7)$ & 161(10) \\
\hline
\end{tabular}

Symmetry transformations used to generate equivalent atoms: $\# 1 \mathrm{x},-\mathrm{y}+3 / 2, \mathrm{z} \# 2 \mathrm{x}-1 / 2, \mathrm{y},-\mathrm{z}+1 / 2 \# 3-\mathrm{x}+1,-\mathrm{y}+1,-\mathrm{z}+1$.

$\# 4-x+3 / 2,-y+1, z+1 / 2 \# 5-x+3 / 2,-y+1, z-1 / 2 \# 6 x+1 / 2, y,-z+1 / 2$.

\#7 x,y,z-1 \#8 x+1/2,y,-z+3/2.

as both donor and acceptor and is involved in hydrogen bonding to carboxylate oxygen atoms $\mathrm{O} 6$ and $\mathrm{O} 7$, respectively. Similarly the lattice water molecule O10 acts as acceptor and is hydrogen bonded to $\mathrm{O} 9$ and to hydrogen atom of one of the coordinated water molecules, O8. The other hydrogen atom of the coordinated water molecule $\mathrm{O} 8$ is bonded to carboxylate oxygen atom O3. Similarly, hydrogen atom of the coordinated water molecule $\mathrm{O} 7$ is bonded to carboxylate oxygen atom $\mathrm{O} 4$. The hydrogen bonds are also supplemented by $\mathrm{C}-\mathrm{H}$. . O hydrogen bonding interaction between $\mathrm{C} 2$ carbon and carboxylate oxygen atom, $\mathrm{O} 2$. These observations indicate that the noncovalent interactions provide significant contribution to the stabilisation of the $2 \mathrm{D}$ framework. Figure 8 shows the hydrogen bonding in $\left(\left[\mathrm{Ce}_{2}(\mathrm{glu})_{3}\left(\mathrm{H}_{2} \mathrm{O}\right)_{4}\right] \cdot 10 \mathrm{H}_{2} \mathrm{O}\right)_{\mathrm{n}}$.

\section{$3.4 \quad$ FT-IR spectral studies}

FT-IR spectral studies were carried out to analyze the functional groups present in the complex and the resulting spectrum is shown in Figure S2 (Supplementary Information). The spectrum shows a broad band of $\mathrm{OH}$ stretching vibration of water molecules at $3413 \mathrm{~cm}^{-1}$. The strong band at $1700 \mathrm{~cm}^{-1}$ attributed to $v(\mathrm{C}=\mathrm{O})$ vibration of carboxylic acid group of the free ligand is absent in the spectrum of the complex indicating coordination of ligand to the metal through carboxylate group after deprotonation. ${ }^{30}$ The asymmetric and symmetric stretching vibrations of the carboxylate group are observed at 1540 and $1417 \mathrm{~cm}^{-1}$, respectively. A weak absorption band at $2970 \mathrm{~cm}^{-1}$ is attributed to $v(\mathrm{CH})$ vibration of $\mathrm{CH}_{2}$ group. ${ }^{31}$ Stretching vibration of 


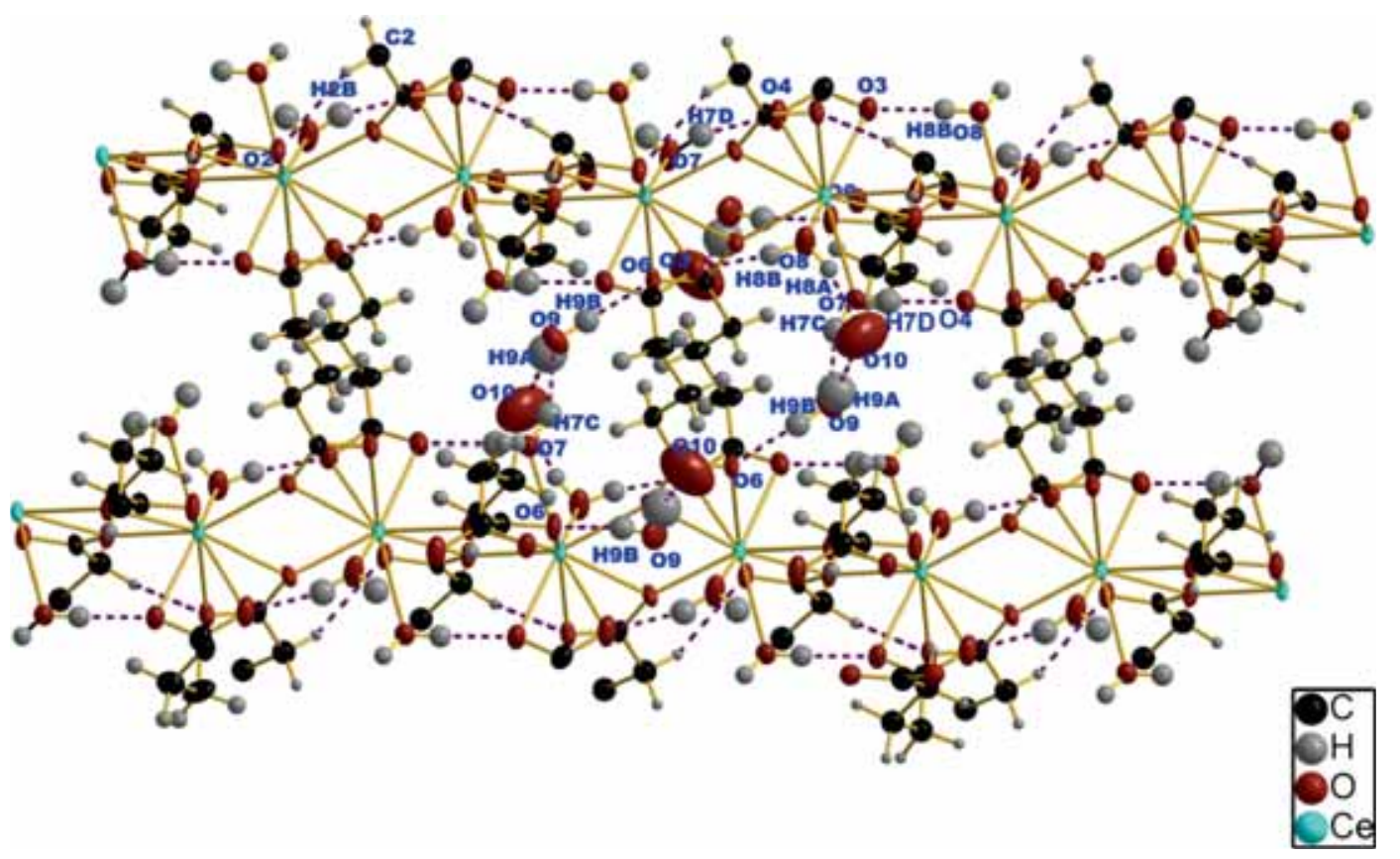

Figure 8. Hydrogen bonding interactions in $\left(\left[\mathrm{Ce}_{2}(\mathrm{glu})_{3}\left(\mathrm{H}_{2} \mathrm{O}\right)_{4}\right] \cdot 10 \mathrm{H}_{2} \mathrm{O}\right)_{\mathrm{n}}$.

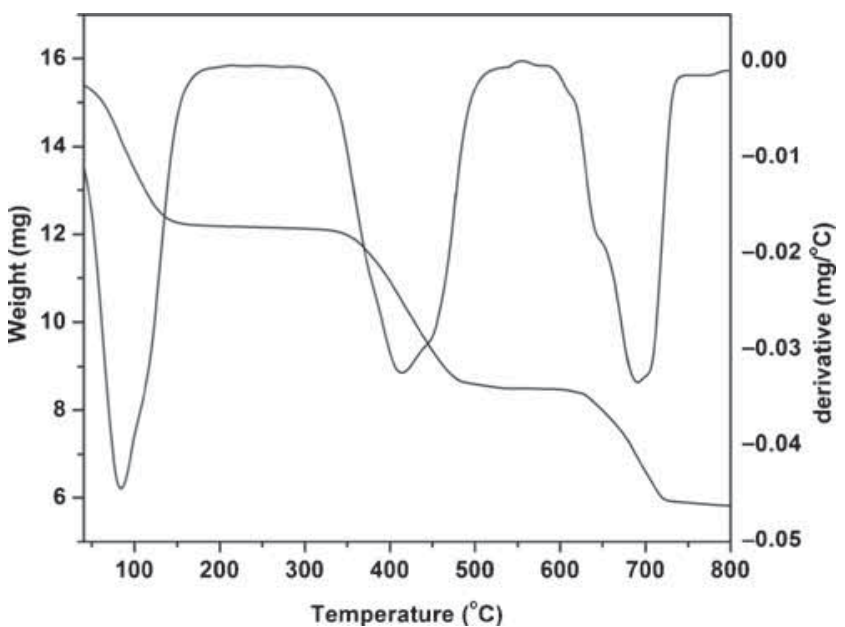

Figure 9. TG/DTG curve of $\left(\left[\mathrm{Ce}_{2}(\mathrm{glu})_{3}\left(\mathrm{H}_{2} \mathrm{O}\right)_{4}\right] \cdot 10 \mathrm{H}_{2} \mathrm{O}\right)_{\mathrm{n}}$.

$\mathrm{C}-\mathrm{C}$ bond appears at $1058 \mathrm{~cm}^{-1}$. The bending vibration of $\mathrm{COO}^{-}$is observed at $645 \mathrm{~cm}^{-1}$.

\subsection{Thermogravimetry}

The thermal decomposition behaviour of the crystals was investigated and the thermogram is shown in Figure 9. From the figure, it is clear that the compound decomposes in three stages. The first weight loss of $14.59 \%$ in the temperature range $70-230^{\circ} \mathrm{C}$ corresponds to the loss of water molecules (calculated: $14 \%$ ). The next two stages correspond to the total removal of the organic ligand moiety with the formation of

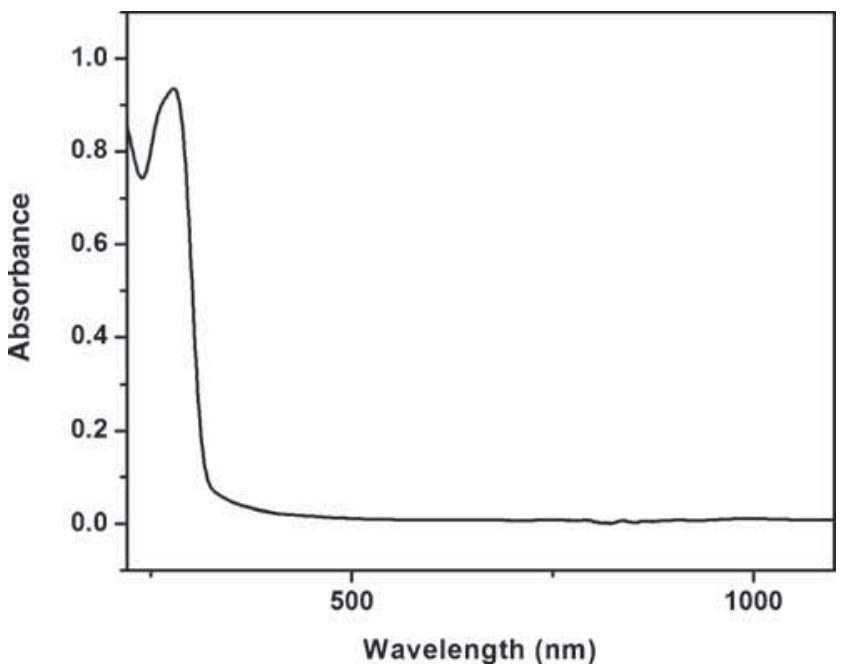

Figure 10. UV-Visible spectrum of $\left(\left[\mathrm{Ce}_{2}(\mathrm{glu})_{3}\left(\mathrm{H}_{2} \mathrm{O}\right)_{4}\right]\right.$. $\left.10 \mathrm{H}_{2} \mathrm{O}\right)_{\mathrm{n}}$.

corresponding metal oxide as the final product. The observed and calculated mass losses are 57.21 and $56.78 \%$, respectively.

\subsection{UV-Visible absorbtion studies}

The UV-Visible absorption spectrum is shown in Figure 10. The spectrum of $\mathrm{Ce}(\mathrm{III})$ is quite different as compared to other lanthanide compounds. The lowest energy transition of $\mathrm{Ce}(\mathrm{III})$ involves the promotion of an electron from $4 \mathrm{f}$ to the $5 \mathrm{~d}$ orbitals. Since the ground and the excited states of this $\mathrm{f}^{1}$ ion are spin doublets, all 
transitions are spin-allowed. The corresponding absorptions appear in the UV region. The single absorption peak at $278 \mathrm{~nm}$ is due to the $4 \mathrm{f}-5 \mathrm{~d}$ electronic transitions in $\mathrm{Ce}^{3+}$ ions. From the spectrum, it is clear that, the crystals are transparent in the entire visible region. Generally, $\mathrm{Ce}$ (III) complexes are colourless since the metal centred f-d transition gives rise to an absorption in the near UV region. The free acid is also colourless so upon coordination, the intraligand bands remain in the UV region. ${ }^{32}$

\subsection{Photoluminescence studies}

Lanthanide complexes play an important role in luminescence spectroscopy. The chemical structure and the tunability of the position of the strong $4 \mathrm{f}-5 \mathrm{~d}$ absorption and the corresponding emissions make $\mathrm{Ce}^{3+}$ ion one of the important constituents in light emitting materials. ${ }^{33,34}$ The solid state PL spectrum of the complex was recorded using JY Horiba PL meter at room temperature with an excitation wavelength of $300 \mathrm{~nm}$ and the spectrum is displayed in Figure 11. The spectrum of Ce(III) shows broad emission band as the emission which result from $4 \mathrm{f}-5 \mathrm{~d}$ transitions are generally broad. Usually, $\mathrm{Ce}^{3+}$ emission appears in the UV or blue spectral region. ${ }^{35}$ Moreover, Ce(III) lacks an effective $\mathrm{f}$ shield and is thus influenced by the crystal field of the ligand leading to the broadening of the emission band. ${ }^{36}$

\subsection{Magnetic susceptibility}

The solid state room temperature magnetic susceptibility of the compound was performed on a Sherwood Scientific

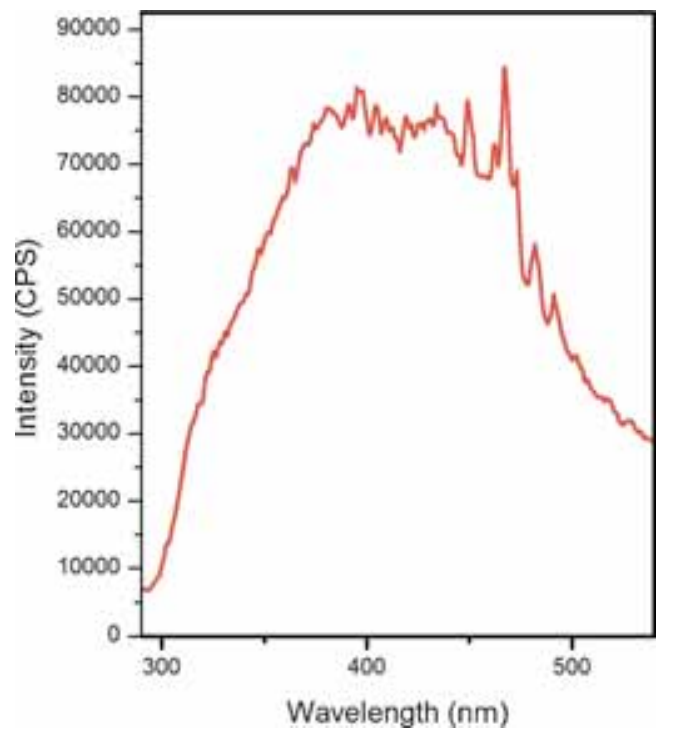

Figure 11. Room temperature solid state photoluminescence spectrum of $\left(\left[\mathrm{Ce}_{2}(\mathrm{glu})_{3}\left(\mathrm{H}_{2} \mathrm{O}\right)_{4}\right] \cdot 10 \mathrm{H}_{2} \mathrm{O}\right)_{\mathrm{n}}$.
MK-1 magnetic susceptibility meter. In lanthanides, paramagnetism is due to the presence of $4 \mathrm{f} \mathrm{elec-}$ trons that were effectively shielded by $5 s^{2} 5 p^{6}$ electrons. Moreover, the spin orbital coupling for the unpaired electrons in the $f$ orbitals of the lanthanides is quite strong. Usually, $\mathrm{Ce}$ (III) complexes show effective magnetic moment in the range $2.34-2.57 \mathrm{BM}^{37}$ In the case of $\left(\left[\mathrm{Ce}_{2}(\mathrm{glu})_{3}\left(\mathrm{H}_{2} \mathrm{O}\right)_{4}\right] \cdot 10 \mathrm{H}_{2} \mathrm{O}\right)_{\mathrm{n}}$, effective magnetic moment was calculated using the relation $\mu_{\text {eff }}=2.828$ $\left(\mathrm{X}_{\mathrm{m}} \mathrm{T}\right)^{1 / 2}$, where $\mathrm{X}_{\mathrm{m}}$ is the molar susceptibility corrected using Pascals constants. ${ }^{38}$ The data showed that the compound is paramagnetic with $\mu_{\text {eff }}=2.56$ B.M..

\section{Conclusions}

A novel 2D metal-organic framework, poly[tetraaquatriglutaratodicerium(III) decahydrate] was successfully grown by single gel diffusion technique at room temperature. The crystals obtained were transparent and needle shaped. Single crystal X-ray diffraction study revealed that the compound is a porous metal-organic framework which crystallizes in orthorhombic space group Pnma. The metal coordination give rise to $1 \mathrm{D}$ chains which are further connected by glutarate ligands to form a 2D architecture. One of the important structural features of the compound is the presence of hydrophilic hexagonal channels. The stoichiometry of the compound was analyzed by elemental analysis and the molecular formula obtained, $\left(\left[\mathrm{Ce}_{2}(\mathrm{glu})_{3}\left(\mathrm{H}_{2} \mathrm{O}\right)_{4}\right] \cdot 10 \mathrm{H}_{2} \mathrm{O}\right)_{\mathrm{n}}$ is in accordance with single crystal X-ray diffraction results. The FT-IR spectral studies showed that the ligand is coordinated to the metal through carboxylate oxygen atom. Powder X-ray diffractogram confirmed the bulk purity and crystalline nature of the grown crystal. The thermogram showed that the compound decomposes in three stages and oxide of cerium was obtained as the final decomposition product. The optical absorption study indicated that the compound is transparent in visible region. The photoluminescence spectrum showed a broad emission band. Magnetic studies revealed paramagnetic behaviour of the complex with one unpaired electron.

\section{Supplementary Information (SI)}

CCDC 1016358 contains the supplementary crystallographic data for the compound $\left(\left[\mathrm{Ce}_{2}(\mathrm{glu})_{3}\right.\right.$ $\left.\left.\left(\mathrm{H}_{2} \mathrm{O}\right)_{4}\right] \cdot 10 \mathrm{H}_{2} \mathrm{O}\right)_{\mathrm{n}}$. These data can be obtained free of charge via www.ccdc.cam.ac.uk/conts/retrieving.html, or from the Cambridge Crystallographic Data Centre, 12 Union Road, Cambridge CB2, 1EZ, UK; Fax: $(+44)$ 1223-336-033, or e-mail: deposit@ccdc.cam.ac.uk. Some selected bond lengths and bond angles of the 
compound (Table S1), Diamond drawing of the asymmetric unit excluding lattice water molecules (Figure S1), FT-IR spectrum (Figure S2) and check cif file are given in Supplementary Information, which are available at www.ias.ac.in/chemsci.

\section{Acknowledgements}

The authors are grateful to the authorities of Sophisticated Analytical Instrumental Facilities (SAIF), Cochin University of Science and Technology, Kochi and M G University, Kottayam for providing the instrumental facilities.We are also thankful to Dr. Shibu M Eapen, SAIF, CUSAT, Kochi for single crystal X-ray diffraction measurements. The corresponding author is grateful to the University Grants Commission (UGC) for the sanction of a minor research project (MRP(S)-0270/1213/KLKE027/UGC-SWRO). RMN is grateful to the University of Kerala for the award of a Fellowship.

\section{References}

1. Roswell J L C and Yaghi O M 2004 Microporous Mesoporous Mater. 733

2. Ma S and Zhou H-C 2010 Chem. Commun. 4644

3. Chouhan A, Pandey A and Mayer P 2015 J. Chem. Sci. 1271599

4. Lee J, Farha O K, Roberts J, Scheidt K A, Nguyen S T and Hupp J T 2009 Chem. Soc. Rev. 381450

5. Nalaparaju A and Jiang J 2012 J. Phys. Chem. 1166925

6. Natarajan S, Mahata P and Sarma D 2012 J. Chem. Sci. 124339

7. Gandara F, de Andres A, Gomez-Lor B, GutierrezPuebla E, Iglesias M, Monge M A, Prosperpio D M and Snejko N 2008 Cryst. Growth Des. 8378

8. Perles J, Iglesias M, Ruiz-Valero C and Snejko N 2004 J. Mater. Chem. 142683

9. Cao X, Yu L and Huang R 2014 J. Solid State Chem. 21074

10. Chen Y and Ma S 2012 Rev. Inorg. Chem. 3281

11. Rocha J, Carlos L D, Almeida Paz F A and Ananias D 2011 Chem. Soc. Rev. 40926

12. Anoop M R, Binil P S, Suma S and Sudarsanakumar M R 2012 J. Rare Earths 30709

13. Huang W, Wu D, Zhou P, Yan W B, Guo D, Duan C Y and Meng Q J 2009 Cryst. Growth Des. 91361
14. Sun J and Zheng Y-Q 2003 Z. Anorg. Allg. Chem. 629 1001

15. Lee E W, Kim Y J and Jung D-Y 2002 Inorg. Chem. 41501

16. Rao C N R, Natarajan S and Vaidhyanathan R 2004 Angew. Chem. Int. Ed. 431466

17. Ren Y P, Long L S, Mao B W, Yuan Y Z, Huang R B and Zheng L S 2003 Angew. Chem. Int. Ed. 42532

18. Aliouane K, Djeghri A, Guehria-Laidoudi A, Dahaoui S and Lecomte C 2007 J. Mol. Struct. 832150

19. Rahahlia N, Benmerad B, Guehria-Laidoudi A, Dahaoui S and Lecomte C 2006 Acta Cryst. E 622145

20. Roy S M, Sudarsanakumar M R, Suma S, Kurup M R P and Dhanya V S 2013 J. Inorg. Organomet. P. 23608

21. Nair R M, Sudarsanakumar M R, Suma S, Kurup M R P and Antarjanam P K S 2016 Inorg. Chem. Commun. 6381

22. Nair R M, Sudarsanakumar M R, Suma S and Kurup M R P 2016 J. Mol. Struct. 1105316

23. APEXII and SAINT 2004 (Bruker AXS: Madison, WI)

24. Sheldrick G M 1997 In SHELXL 97 Program for Crystal Structure Refinement (Gottingen, Germany: University of Gottingen)

25. Brandenburg K 2008 In DIAMOND Version 3.1f (Bonn: Crystal Impact, GbR)

26. Bruno I J, Cole J C, Edgington P R, Kessler M, Macrae C F, McCabe P, Pearson J and Taylor R 2002 Acta. Cryst. 58B 389

27. Oh Y, Kim J Y, Kim H J, Lee T and Kang S W 2010 Bull. Kor. Chem. Soc. 311058

28. Millward A R and Yaghi O M 2005 J. Am. Chem. Soc. 12717998

29. Ma S 2009 Pure Appl. Chem. 812235

30. Mitra T, Sailakshmi G and Gnanamani A 2014 J. Chem. Sci. 126127

31. Hou K-L, Bai F-Y, Xing Y-H, Wang J-L and Shi Z 2011 Inorg. Chim. Acta 365269

32. Vogler A and Kunkely H 2006 Inorg. Chim. Acta 359 4130

33. Trusova E E, Bobkova N M, Gurin V S and Tyavlovskaya E A 2006 Glass Ceram. 667

34. Prokhorova T I and Ostrogina O M 1981 Fiz. Khim. Stekla 7678

35. Blasse G and Brill A 1967 J. Chem. Phys. 475139

36. de Oliveira C A F, da Silva F F, Malvestiti I, Malta V R S, Dutra J D L, da Costa Jr. N B, Freire R O and Alves S 2013 J. Mol. Struct. 104161

37. El-Wahab Z H A, Mashaly M M and Faheim A A 2005 Chem. Pap. - Chem. Zvesti 3525

38. Gordon A B and John F B J 2008 Chem. Edn. 85532 